\title{
Symmetrical Exsolution of Rh Nanoparticles in Solid Oxide Cells for Efficient Syngas Production from Greenhouse Gases
}

Vasileios Kyriakou, *, Dragos Neagu ${ }^{2}$, Georgios Zafeiropoulos ${ }^{1}$, Rakesh Kumar Sharma ${ }^{l}$, Chenyang Tang ${ }^{2}$, Kalliopi Kousi ${ }^{2}$, Ian S. Metcalfe ${ }^{2}$, Mauritius C.M. van de Sanden ${ }^{1}$ and Mihalis N. Tsampas ${ }^{1}$

${ }^{1}$ Dutch Institute for Fundamental Energy Research (DIFFER), 5612 AJ Eindhoven, the Netherlands , ${ }^{2}$ School of Engineering, Newcastle University, UK

\begin{abstract}
Carbon dioxide and steam solid oxide co-electrolysis is a key technology for exploiting renewable electricity to generate syngas feedstock for the Fischer-Tropsch synthesis. The integration of this process with methane partial oxidation in a single cell can eliminate or even reverse the electrical power demands of co-electrolysis, while simultaneously producing syngas at industrially attractive $\mathrm{H}_{2} / \mathrm{CO}$ ratios. Nevertheless, this system is rather complex, and requires catalytically active and coke tolerant electrodes. Here, we report on a low-substitution rhodium-titanate perovskite $\left(\mathrm{La}_{0.43} \mathrm{Ca}_{0.37} \mathrm{Rh}_{0.06} \mathrm{Ti}_{0.94} \mathrm{O}_{3}\right.$ ) electrode for the process, capable of exsolving high $\mathrm{Rh}$ nanoparticle populations, and assembled in a symmetrical solid oxide cell configuration. By introducing dry methane to the anode compartment, the electricity demands are impressively decreased, even allowing syngas and electricity cogeneration. To provide further insight on $\mathrm{Rh}$ nanoparticles role on methane-to-syngas conversion, we adjusted their size and population by altering the reduction temperature of the perovskite. Our results exemplify how the exsolution concept can be employed to efficiently exploit noble metals for activating low-reactivity greenhouse gases in challenging energy related applications.
\end{abstract}




\section{KEYWORDS}

exsolution; syngas production; methane partial oxidation; $\mathrm{CO}_{2}-\mathrm{H}_{2} \mathrm{O}$ solid oxide co-electrolysis; Rh catalyst; greenhouse gases

\section{INTRODUCTION}

The solid oxide co-electrolysis of steam and carbon dioxide,

$\mathrm{CO}_{2}+\mathrm{H}_{2} \mathrm{O} \rightarrow \mathrm{CO}+\mathrm{H}_{2}+\mathrm{O}_{2} \quad \Delta H_{\mathrm{R}, 298 \mathrm{~K}}=524.8 \mathrm{~kJ} \cdot \mathrm{mol}^{-1}$

powered by renewable electricity is a clean and efficient technology to produce syngas $\left(\mathrm{CO}+\mathrm{H}_{2}\right)$ feedstock for the production of higher alkanes and oxygenates via the Fischer-Tropsch (F-T) process $^{1-5}$. Thereby, intermittent renewable electricity could be stored in chemical bonds and concurrently, the huge capital investments required to modify the existing liquid hydrocarbon infrastructure could be circumvented ${ }^{1-5}$.

In conventional solid oxide electrolysis cells (SOECs), Ni-based cermets are commonly employed as the fuel electrodes (cathodes) ${ }^{4-15}$. Their microstructure, however, is sensitive to redox conditions that dominate co-electrolysis, causing significant losses in electrical conductivity and electrocatalytic activity during long-term operation ${ }^{6}$. To maintain stable performance, reducing agents, such as hydrogen or carbon monoxide, are co-fed with steam and/or carbon dioxide to prevent $\mathrm{Ni}$ oxidation ${ }^{4-15}$. At the same time, the oxygen formed at the cathode is recovered through the solid electrolyte and is routinely evolved into an air stream at the anode. The above described combination leads to a large oxygen partial pressure gradient across the electrolyte, which increases the chemical potential barrier and thus, the Nernst potential for oxygen anion transport ${ }^{16-}$ 18 .

By supplying a fuel instead of air over the anode the electrical energy demands can be reduced, eliminated or even reversed ${ }^{19,20}$. The concept of the simultaneous cathodic co-electrolysis and the anodic fuel oxidation has been principally examined in the case of methane (Fig. 1a) due to its low cost and abundancy, as well as the possible formation of value-added chemicals from an important greenhouse gas ${ }^{16-18,21-30 \text { : }}$ 

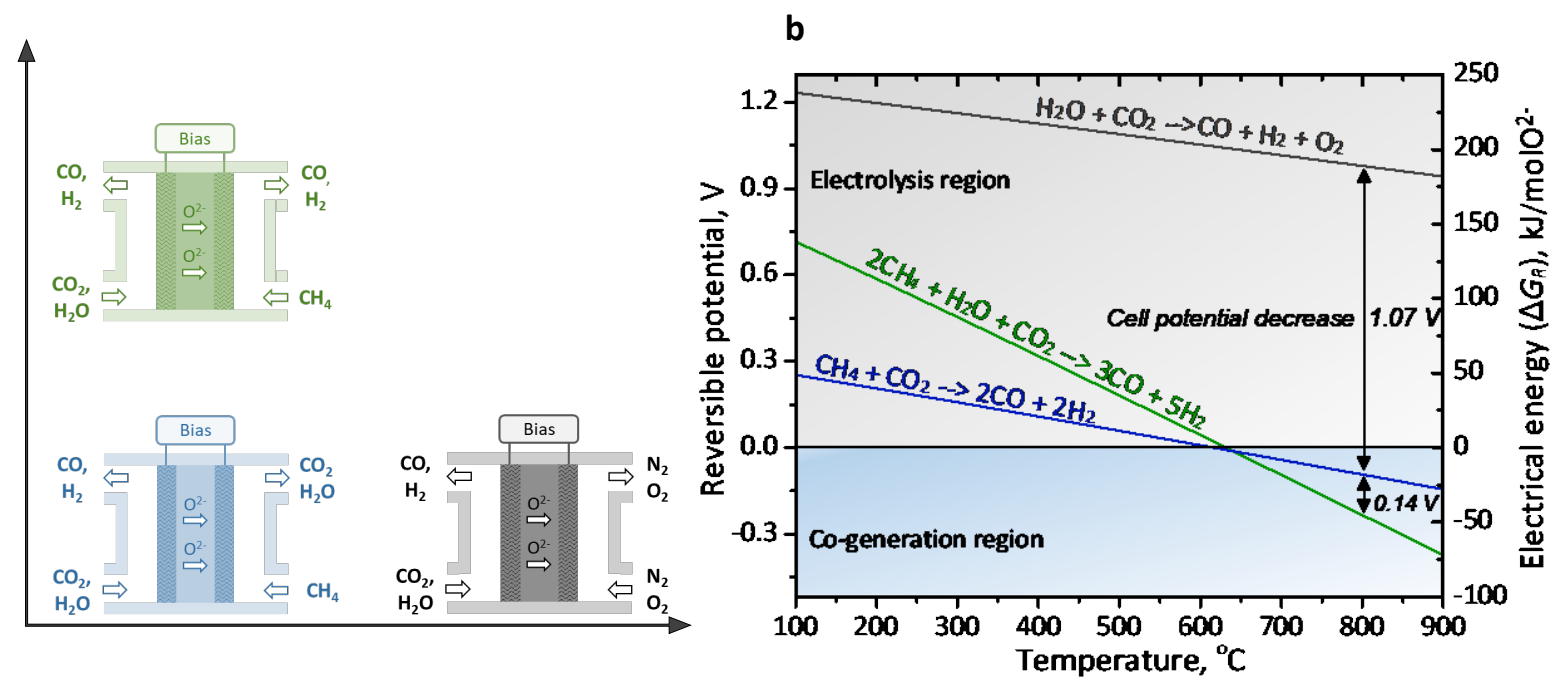

Figure 1. The methane-assisted $\mathrm{CO}_{2}-\mathrm{H}_{2} \mathrm{O}$ co-electrolysis concept. a. Schematic with the possible reactions on each electrode. b. Minimum electrical power requirements and reversible potential for syngas generation, resulting from the various overall reactions $((1),(4)$ and (6)) in the cell.

Cathodic half-cell reaction: $\mathrm{CO}_{2}+\mathrm{H}_{2} \mathrm{O}+4 \mathrm{e}^{-} \rightarrow \mathrm{CO}+\mathrm{H}_{2}+2 \mathrm{O}^{2-}$

Partial oxidation of methane (POM) at the anode

Anodic half-cell reaction: $\quad 2 \mathrm{CH}_{4}+2 \mathrm{O}^{2-} \rightarrow 2 \mathrm{CO}+4 \mathrm{H}_{2}+4 \mathrm{e}^{-}$

Overall cell reaction: $2 \mathrm{CH}_{4}+\mathrm{CO}_{2}+\mathrm{H}_{2} \mathrm{O} \rightarrow 3 \mathrm{CO}+5 \mathrm{H}_{2}, \Delta H_{\mathrm{R}, 298 \mathrm{~K}}=226.4 \mathrm{~kJ} \cdot \mathrm{mol}_{\mathrm{CH} 4}{ }^{-1}$

Complete oxidation of methane (COM) at the anode

Anodic half-cell reaction: $\quad \mathrm{CH}_{4}+4 \mathrm{O}^{2-} \rightarrow \mathrm{CO}_{2}+2 \mathrm{H}_{2} \mathrm{O}+8 \mathrm{e}^{-}$

Overall cell reaction: $\mathrm{CH}_{4}+\mathrm{CO}_{2} \rightarrow 2 \mathrm{CO}+2 \mathrm{H}_{2}, \quad \Delta H_{\mathrm{R}, 298 \mathrm{~K}}=247.4 \mathrm{~kJ} \cdot \mathrm{mol}_{\mathrm{CH}_{4}}{ }^{-1}$ (6)

The Gibbs energy (electrical power demands) and consequently, the reversible potential $\left(\mathrm{E}^{\mathrm{o}}=\Delta G_{R} / \mathrm{nF}\right)$ of the aforementioned reaction schemes is considerably lower than $\mathrm{CO}_{2}-\mathrm{H}_{2} \mathrm{O}$ coelectrolysis in a conventional electrolyzer (Fig. 1b). Interestingly, in the temperature range of practical interest for SOECs (i.e. $700-900{ }^{\circ} \mathrm{C}$ ), $\Delta G_{R}$ becomes negative and therefore, the cathodic co-electrolysis (and syngas production) is accompanied by a noteworthy electricity generation. 
The methane assisted co-electrolysis process constitutes a rather complex system, involving three (or more) processes of multiple reacting species and reactions. At the cathode side, the reactions are identical to the conventional $\mathrm{CO}_{2}-\mathrm{H}_{2} \mathrm{O}$ co-electrolysis. Here, the composition of the cathode effluents is dictated not only by the individual $\mathrm{CO}_{2}$ or $\mathrm{H}_{2} \mathrm{O}$ electrolysis reactions, but also by the equilibrium of the reverse water-gas-shift (rWGS) $)^{6-11}$,

$\mathrm{CO}_{2}(\mathrm{~g})+\mathrm{H}_{2}(\mathrm{~g}) \rightarrow \mathrm{CO}(\mathrm{g})+\mathrm{H}_{2} \mathrm{O}(\mathrm{g}), \Delta \mathrm{H}^{\mathrm{o}}=41.2 \mathrm{~kJ} \cdot \mathrm{mol}^{-1}$

To this day, the majority of the works in literature with Ni/YSZ cermet electrodes, agree that carbon monoxide at the cathode is principally formed by rWGS (hydrogen is co-fed to protect $\mathrm{Ni}$ from oxidation) rather than the direct electroreduction of $\mathrm{CO}_{2}{ }^{1,4,8-11}$.

At the anode side, POM is preferable than the COM due to the formation of extra syngas at an ideal $\mathrm{H}_{2} / \mathrm{CO}$ ratio for F-T synthesis (i.e. 2.0), and the greater capability for electrical power generation at high temperatures (Fig.1b). To acquire this desirable operation, however, the anode should exhibit high catalytic activity towards POM and chemical stability in the presence of hydrocarbons. The latter constraint rules out Ni-based cermets due to their limited coking tolerance, particularly in the absence of steam. As a result, the POM-assisted co-electrolysis process concept has been mainly investigated over $\mathrm{Sr}_{2} \mathrm{Fe}_{1.5} \mathrm{Mo}_{0.5} \mathrm{O}_{6-\delta}$ ( $\mathrm{SFM}$ ) perovskites ${ }^{24-26}$. To boost the limited electrocatalytic performance of these perovskites $\mathrm{Ni}$ or $\mathrm{Ru}$ infiltration has been examined $^{26,29}$. Although, metal infiltration enhances the catalytic activity and electronic conductivity of the perovskite, the long-term performance is questionable because of the intense metal agglomeration at elevated temperatures. An interesting approach was proposed for the POMassisted $\mathrm{CO}_{2}$ electrolysis by employing a $\mathrm{La}_{0.75} \mathrm{Sr}_{0.25} \mathrm{Cr}_{0.5} \mathrm{Mn}_{0.5} \mathrm{O}_{3-\mathrm{d}}$ (LSCM) perovskite decorated with exsolved $\mathrm{Cu}-\mathrm{Ni}$ bimetallic nano-phases ${ }^{30}$. This electrode was assembled in a symmetrical configuration, exhibiting high electrocatalytic activity due to the anchored $\mathrm{Cu}-\mathrm{Ni}$ nanoparticles ${ }^{30}$.

Lanthanum titanates are a class of perovskites with excellent chemical, thermal and mechanical stability and thus, have been successfully applied as electrode composites in solid oxide electrochemical processes ${ }^{31-37}$. Additionally, by controlling the deficiency of the A-site, metal nanoparticles from the B-site exsolve on the surface from the perovskite scaffold under reducing conditions $^{32-39}$. The nanoparticles are uniformly decorated over the perovskite and strongly interact with the perovskite backbone due to their socketing nature. This characteristic structure renders 
them more active and stable against coarsening and coking at high temperatures compared to the supported counterparts prepared by infiltration ${ }^{30,34-39}$.

Herein, we design a new perovskite for the $\mathrm{CH}_{4}$-assisted $\mathrm{CO}_{2}-\mathrm{H}_{2} \mathrm{O}$ co-electrolysis process (henceforth referred to as MACE), assembled in a symmetrical cell configuration. The electrode material is a low substitution level rhodium-titanate perovskite, $\mathrm{La}_{0.43} \mathrm{Ca}_{0.37} \mathrm{Rh}_{0.06} \mathrm{Ti}_{0.94} \mathrm{O}_{3}$ (LCT$\mathrm{Rh})$, capable of exsolving high populations $\left(5,100-11,000\right.$ particles $\left.\cdot \mu \mathrm{m}^{2}\right)$ of $\mathrm{Rh}$ nanoparticles $(2.1$ $3.2 \mathrm{~nm}$ ). The titanate perovskites display excellent robustness among perovskites ${ }^{31,34,35,38}$, whereas $\mathrm{Rh}$ is one of the most active catalysts for methane $\mathrm{e}^{40-49}$ and carbon dioxide activation ${ }^{48-54}$. We exemplify how the introduction of $\mathrm{CH}_{4}$ at the anode decreases or even reverses the electrical power demands of the conventional co-electrolysis by simultaneously producing syngas with an up to $100 \%$ selectivity. Our results demonstrate that the exsolution concept can be employed to efficiently exploit noble metals in order to activate low reactivity greenhouse gases, such as $\mathrm{CH}_{4}$ and $\mathrm{CO}_{2}$, in challenging energy-related processes.

\section{RESULTS AND DISCUSSION}

\section{Electrode nanostructuring by exsolution}

The phase purity and crystal structure of the $\mathrm{La}_{0.43} \mathrm{Ca}_{0.37} \mathrm{Rh}_{0.06} \mathrm{Ti}_{0.94} \mathrm{O}_{3}$ powder prepared in air at $1100{ }^{\circ} \mathrm{C}$ was investigated by room temperature XRD and Rietveld refinement over a wide $2 \theta$ range $\left(20-90^{\circ}\right)$. A single perovskite phase of Ibmm type structure (see Fig. 2a) was observed with a slight phase tilting described by $\mathrm{a}^{0} \mathrm{~b}^{-} \mathrm{b}^{-}$in the Glazer tilt notation. Fig.2a also illustrates the visualization of the cubic perovskite structure obtained from the Rietveld refinement and CrystalMaker X. The elemental quantification from the XPS spectra (Fig.2c) revealed an atomic ratio between $\mathrm{La} / \mathrm{Ca} / \mathrm{Rh} / \mathrm{Ti}$ was $1.00 / 0.61 / 0.03 / 1.73$. This is consistent with previous studies whereby during high temperature sintering perovskites exhibit an A-cation (e.g. La) rich surface composition $^{33,36,39}$. Another notable feature displayed in Figs. $2 \mathrm{~b}$ and 2e is rhodium existence as an oxide in the as-prepared sample, which combined with the single perovskite phase shown in $\mathrm{XRD}$ supports the successful incorporation of $\mathrm{Rh}$ in the host perovskite lattice. 

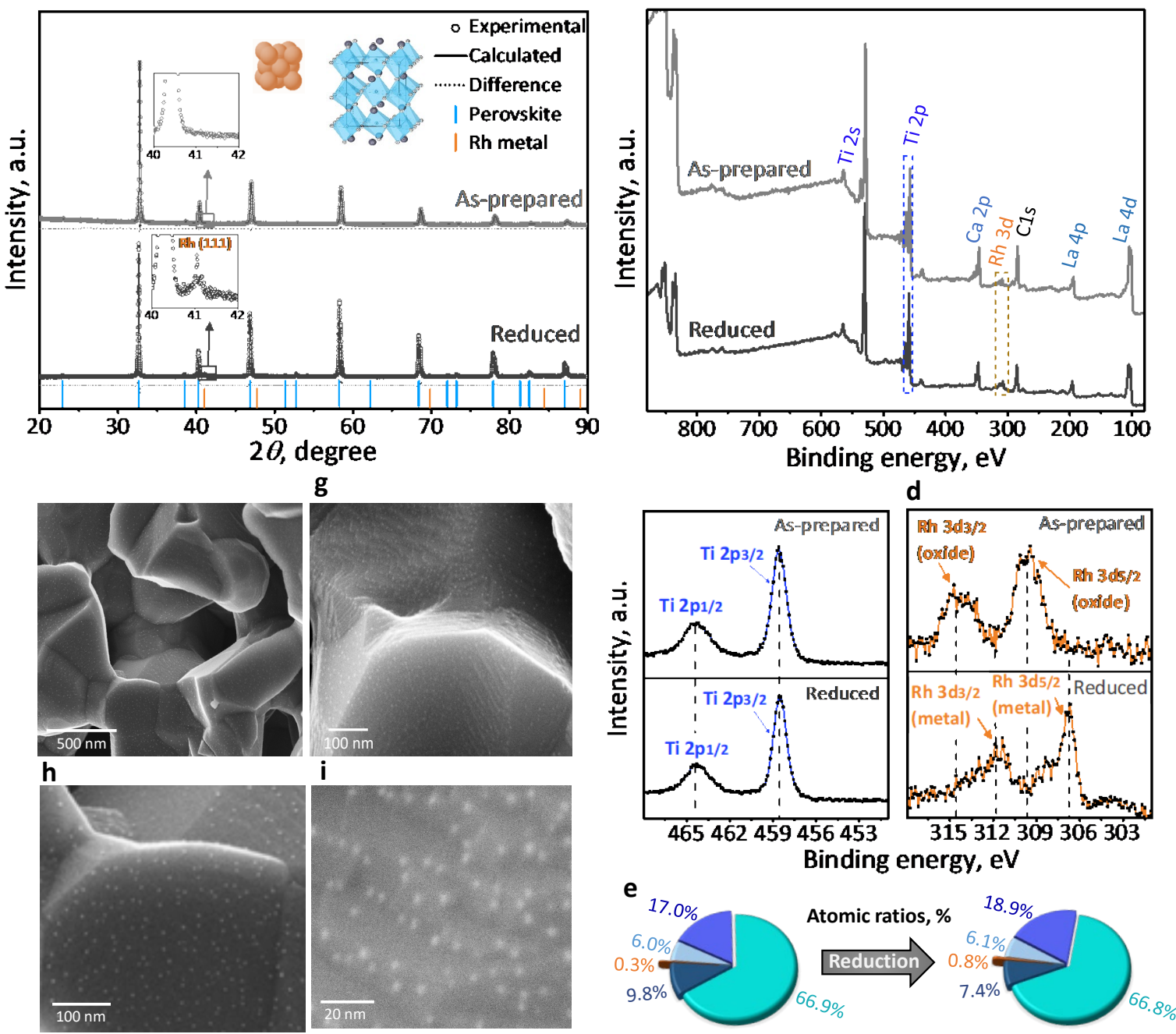

Figure 2. Crystallographic, surface and microstructure analysis of LCT-Rh perovskite. a. Room temperature X-ray diffraction (XRD) patterns and the corresponding Rietveld Refinement analysis of the perovskite (Ibmm, as-prepared: $a=5.4763 \AA, b=5.4661 \AA, c=7.7211 \AA$, reduced: $\mathrm{a}=5.4797 \AA, \mathrm{b}=5.4811 \AA, \mathrm{c}=7.7428 \AA$ ). b. XPS survey. Surface analysis for c. Ti and d. Rh. e. Quantification chart pies of LCT-Rh sample prior and following reduction at $900{ }^{\circ} \mathrm{C}$ f.-i. Representative SEM images of the reduced LCT-Rh, where Rh nanoparticles (3.2 nm average size, $\sim 5,100$ particles $\cdot \mu \mathrm{m}^{-2}$ ) can be seen as bright white spots.

The LCT-Rh was then exposed to $5 \% \mathrm{H}_{2} / \mathrm{N}_{2}$ at $900{ }^{\circ} \mathrm{C}$ for $10 \mathrm{~h}$ to achieve reduction of the perovskite lattice and subsequent exsolution of $\mathrm{Rh}$ nanoparticles from the perovskite lattice. Upon exposure of the perovskite oxide to a reducing atmosphere, such as hydrogen, oxygen is stripped 
from the lattice, introducing oxygen vacancies apart from the existing A-site vacancies due to deficiency. This process, in combination with the decrease in oxidation state of the reducible ions (e.g. $4 \mathrm{e}^{-}+\mathrm{Rh}^{+4} \rightarrow \mathrm{Rh}^{0}$ ), favor metal nucleation at the surface ${ }^{34,36}$. The SEM images of the sample at various magnifications (Figs. 2f-2i) depict that the surface was decorated with uniformly distributed Rh nanoparticles (bright spots), anchored on surface of the perovskite matrix. Their population was impressive, surpassing 5000 particles per square micron with a diameter size distribution of $2.5-5.0 \mathrm{~nm}$. To verify that these particles are actually $\mathrm{Rh}$ metal, we performed XRD and XPS analysis. The room temperature XRD diffractogram (Fig.2a) revealed the appearance of the $\mathrm{Rh}$ (111) characteristic reflection at $41.1^{\circ}$ after the reduction procedure. Moreover, and in contrast to the as-prepared sample, the binding energies of $\mathrm{Rh} 3 \mathrm{~d}$ after hydrogen exposure shifted to $\sim 307 \mathrm{eV}$ which typically corresponds to $\mathrm{Rh}^{0}$, verifying the existence of metallic rhodium on the surface of the perovskite. Additionally, some $\mathrm{Rh}^{3+}$ was also observed $(\sim 308 \mathrm{eV})$ which most likely corresponds to a surface oxide layer formed due to the exposure of metal $\mathrm{Rh}$ particles to atmospheric oxygen following the reduction procedure. Furthermore, the atomic concentration of B-site cations as calculated by the XPS was considerably increased (Rh: 0.3 to 0.8 and Ti: 17 to $18.9 \%$ ) as compared to the fresh samples.

\section{Effect of anode feed on the cell performance}

To investigate the electro-catalytic performance of these unique nanostructures for the challenging MACE concept, we fabricated a symmetrical LCT-Rh/gadolinia-doped ceria (GDC)-based cells with scandia-ceria stabilized zirconia (ScCeSZ) as the solid electrolyte (Fig.3a). The cell was mounted in the testing apparatus and the temperature was increased to $900{ }^{\circ} \mathrm{C}$ for the reduction procedure. A $5 \% \mathrm{H}_{2} / \mathrm{N}_{2}$ gas mixture was introduced to both anode and cathode compartments for $10 \mathrm{~h}$ to succeed in the decoration of the perovskite with $\mathrm{Rh}$ nanoparticles. Fig.3b-3e illustrate the microstructure of the reduced cell. The thickness of LCT-Rh/GDC composite electrode was around $11 \mu \mathrm{m}$. The much denser GDC interlayer between the composite electrodes and solid electrolyte was $\sim 6 \mu \mathrm{m}$, and exhibited excellent adhesion with the solid electrolyte (Fig.3b). 

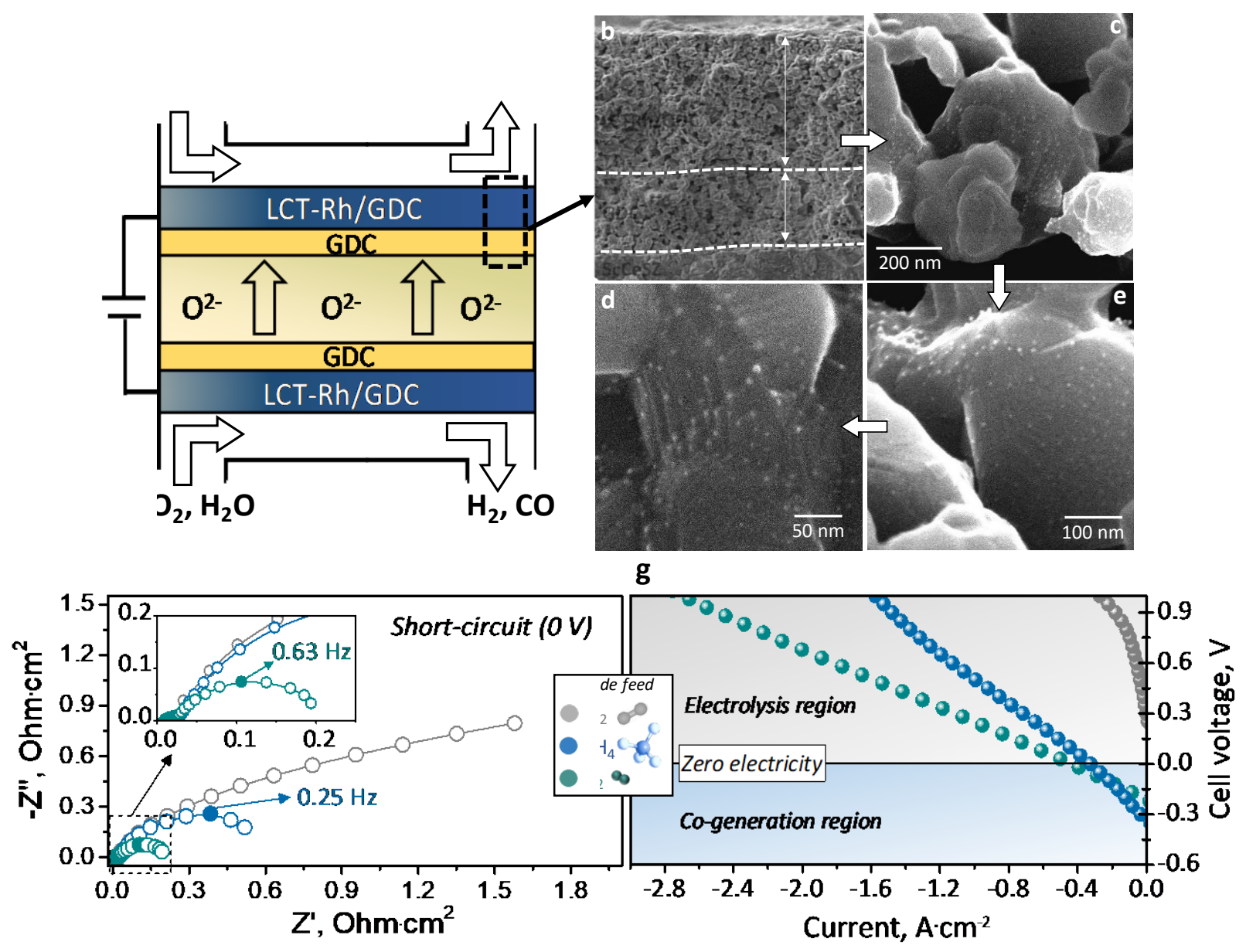

Figure 3. Cell structure and effect of anode gas feed on the cell performance. a. Schematic of LCT-Rh/GDC symmetrical cell and b. the corresponding cross-section SEM image following reduction. c.-e. LCT-Rh/GDC electrode morphology. f. Nyquist plots and g. I-V polarization curves for unassisted $\left(20 \% \mathrm{O}_{2} / \mathrm{N}_{2}\right)$, methane- $\left(40 \% \mathrm{CH}_{4} / \mathrm{N}_{2}\right)$ and hydrogen- $\left(40 \% \mathrm{H}_{2} / \mathrm{N}_{2}\right)$ assisted coelectrolysis of $\mathrm{CO}_{2}-\mathrm{H}_{2} \mathrm{O}$. In all cases the concentration over the cathode was $25 \% \mathrm{CO}_{2}-25 \% \mathrm{H}_{2} \mathrm{O}$ $50 \% \mathrm{~N}_{2}$ and the operation temperature $850{ }^{\circ} \mathrm{C}$.

The temperature was subsequently set at $850{ }^{\circ} \mathrm{C}$ to conduct the electrocatalytic tests. At the cathode side, i.e. the $\mathrm{CO}_{2}-\mathrm{H}_{2} \mathrm{O}$ co-electrolysis chamber, the feed gas concentrations were kept at $25 \% \mathrm{H}_{2} \mathrm{O}-$ $25 \% \mathrm{CO}_{2}-50 \% \mathrm{~N}_{2}\left(1 / 1 \mathrm{CO}_{2} / \mathrm{H}_{2} \mathrm{O}\right)$ with a total volumetric flowrate of $100 \mathrm{sccm}$. Figure $3 \mathrm{f}$ and $3 \mathrm{~g}$ show the effect of anode gas to the cell impedance and I-V characteristics. Initially, a $20 \% \mathrm{O}_{2} / \mathrm{N}_{2}$ feed (synthetic air) at $100 \mathrm{sccm}$ flowrate was introduced to the anode in order to simulate the typical $\mathrm{H}_{2} \mathrm{O}-\mathrm{CO}_{2}$ co-electrolysis process. As seen in Figure $3 \mathrm{~g}$, the current density rapidly rises only after $0.8 \mathrm{~V}$ of applied voltage, as expected for the solid oxide co-electrolysis (Fig.1b). 
However, by switching the anode feed to a fuel, such as dry $\mathrm{H}_{2}$ or $\mathrm{CH}_{4}$ (both $40 \%$ in $\mathrm{N}_{2}$ ), a remarkable shift of the onset potential to the fuel cell region was observed, and therefore, the syngas formation from $\mathrm{CO}_{2}-\mathrm{H}_{2} \mathrm{O}$ at the cathode is accompanied by the generation of electrical power.

The Nyquist plots in Figure $3 \mathrm{f}$ obtained under short-circuit conditions $(0 \mathrm{~V})$ project a remarkable decrease in the cell's polarization resistance (Rp) when air $\left(5.89 \Omega \cdot \mathrm{cm}^{-2}\right)$ is substituted by hydrogen $\left(0.21 \Omega \cdot \mathrm{cm}^{-2}\right)$ or methane $\left(0.62 \Omega \cdot \mathrm{cm}^{-2}\right)$. The first intercept with x-axis (Z' real) of the EIS spectra has been normalized to zero to directly depict the Rp of the cell. Another important feature shown in Figure $3 \mathrm{f}$ is that the predominant source of the cell's resistance is the very low frequency processes $(<1 \mathrm{~Hz})$, which can be related to either fuel oxidation at the anode or $\mathrm{CO}_{2}$ $\mathrm{H}_{2} \mathrm{O}$ co-electrolysis at the cathode. Since the cathodic process was the same in all cases, the only factor varied was the gas feed at the anode, and hence it can be safely assumed that the preeminent part of the resistance is due to the fuel oxidation. The electrochemical performance is connected to the kinetics of oxygen reaction over the anodic electrode. This is also evident by the difference between the resistances of $\mathrm{H}_{2}$ and $\mathrm{CH}_{4}$ feed. Hydrogen molecule exhibits high mobility and reactivity, reacting fast with oxygen species, and thus eliminating concentration of the latter over the anode. On the contrary, methane is a refractory molecule with slower kinetics for oxidation, leading to higher polarization resistances due to increased oxygen partial pressures at the anode. Nevertheless, even though the hydrogen sacrifice can significantly reduce the electrical power demands, methane is a more strategic choice due to its capability to form useful products. Methane oxidation at the anode can attribute both extra syngas and diminished electricity demands to the process, increasing the overall efficiency. Fig. 3 reveals the potential of the Rh nanoparticlesdecorated electrode to perform adequately even under dry methane feed, constituting it ideal for this process.

To evaluate the contribution of $\mathrm{Rh}$ nanoparticles to the overall electrocatalytic performance of the perovskite, an identical symmetrical cell with an undoped $\mathrm{La}_{0.4} \mathrm{Ca}_{0.4} \mathrm{TiO}_{3}$ (LCT) perovskite was fabricated and tested. The impedance spectra under open- and short-circuit conditions, as well as the I-V curves for MACE concept are displayed in Fig. S4. The cell based on the undoped LCT exhibited up to ten times higher Rp than the Rh-doped sample. The lower resistance obtained with LCT-Rh as to LCT is in good agreement with the results in current density (Fig. S4c), further 
confirming that, primarily, methane oxidation and secondarily, carbon dioxide-steam coelectrolysis are remarkably accelerated by the exsolution of $\mathrm{Rh}$ nanoparticles.

\section{Comparison to reference systems}

The performance of LCT-Rh for MACE was also benchmarked against an SFM double perovskite, which constitutes one of the most promising ceramic electrodes reported in literature to date for similar high temperature electrolysis processes ${ }^{24-26}$. SFM was also mixed with GDC at 60/40wt.\% ratio and assembled in a ScCeSZ-based symmetrical configuration for the experimental tests. The characterizations of the SFM/GDC cell, including the crystallographic analysis and microstructure of the composite electrode, as well as its electrocatalytic performance for $\mathrm{CO}_{2}-\mathrm{H}_{2} \mathrm{O}$ co-electrolysis are presented in Figs. S5-S7.

Gas concentrations of $40 \% \mathrm{CH}_{4} / \mathrm{N}_{2}$ and $25 \% \mathrm{H}_{2} \mathrm{O}-25 \% \mathrm{CO}_{2}-50 \% \mathrm{~N}_{2}$ over the anode and cathode, respectively, were selected for MACE studies. At $850^{\circ} \mathrm{C}$, the OCV observed with SFM/GDC was $\sim 0.19 \mathrm{~V}$, representing a $0.15 \mathrm{~V}$ lower capability for cogeneration compared to LCT-Rh cell (OCV $=0.34 \mathrm{~V})$. The maximum current density delivered by SFM/GDC was $0.4 \mathrm{~A} \cdot \mathrm{cm}^{-2}$, whereas with LCT-Rh/GDC exceeded $1.57 \mathrm{~A} \cdot \mathrm{cm}^{-2}$ at $1.0 \mathrm{~V}$ (Fig.4b). The superiority of LCT-Rh nano-structured electrode is even more pronounced at voltages $<0.6 \mathrm{~V}$, where the current density attained with the Rh-based electrode was enhanced by up to 8 times over SFM/GDC. According to thermodynamics, by adding methane the voltage requirements of $\mathrm{CO}_{2}-\mathrm{H}_{2} \mathrm{O}$ co-electrolysis should decline by at least $1.0 \mathrm{~V}$ (Fig. 1b). However, with SFM the onset potential was close to $0.6 \mathrm{~V}$, reduced only by $\sim 0.35$ $\mathrm{V}$ from the minimum voltage for conventional co-electrolysis. A similar decrease in onset potentials as with SFM has been reported in $\mathrm{CH}_{4} / \mathrm{CO}_{2}$ systems, even by using electro-catalysts with exsolution of bimetallic CuNi particles ${ }^{30}$. Yet, here, an impressive drop of the onset potential to the co-generative region was observed in the presence of $\mathrm{Rh}$ exsolved particles, manifesting their essential role in the improvement of electrocatalytic performance.

In the vast majority of the works reported in literature on MACE, methane is mixed with steam before introduced to the anode chamber. Steam addition, however, facilitates $\mathrm{O}^{2-}$ diffusion in the perovskite lattice, and produces syngas via steam-methane reforming under open-circuit conditions. Upon current or voltage imposition and $\mathrm{O}^{2-}$ pumping to the anode, the oxidation of $\mathrm{CO}$ and $\mathrm{H}_{2}$ is much faster than that of the refractory methane molecule, resulting in enhanced current densities (similarly as $\mathrm{H}_{2}$ feed in Fig. 3). Nevertheless, by following this route a major part of the 
b
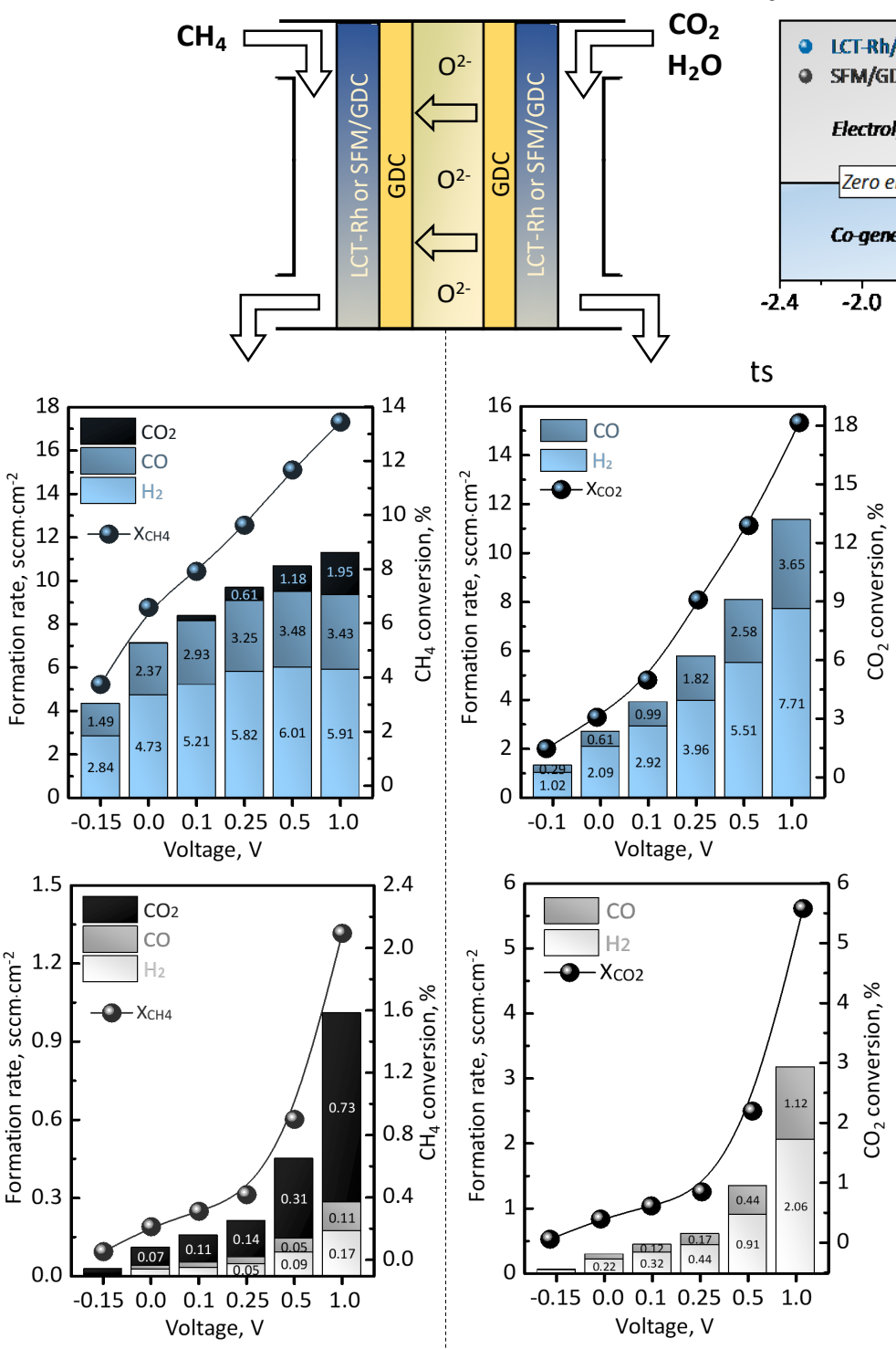

g
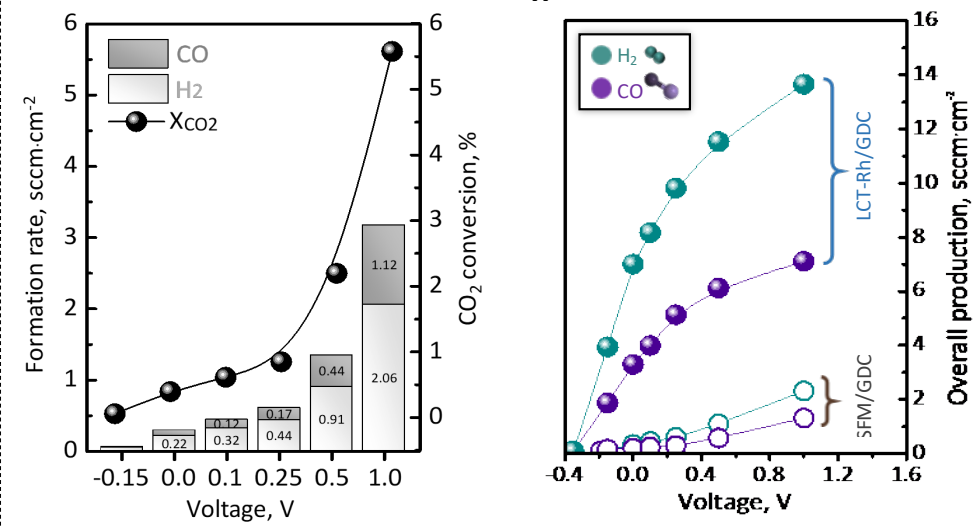

Figure 4. Comparison between LCT-Rh and SFM electro-catalysts for methane-assisted coelectrolysis of $\mathrm{CO}_{2}-\mathrm{H}_{2} \mathrm{O}$ concept. a. Schematic of the cells used and b. the corresponding electrochemical performance of LCT-Rh/GDC and SFM/GDC symmetrical cells. c., d. Anode and e, f. cathode products formation rates at several applied voltages. Overall g. reactants consumption and h. syngas generation in the examined cells. Feed: Anode feed: $40 \% \mathrm{CH}_{4}-60 \% \mathrm{~N}_{2}$, cathode feed: $25 \% \mathrm{CO}_{2}-25 \% \mathrm{H}_{2} \mathrm{O}-50 \% \mathrm{~N}_{2}$. Operation temperature was $850{ }^{\circ} \mathrm{C}$.

useful products is consumed, hence decreasing the overall energy efficiency of the process. To this end, we selected to expose our anodes to the severe dry methane atmospheres in order to accurately 
determine their activity for the challenging methane oxidation. The effluents of both compartments were continuously monitored by means of gas-chromatography and mass-spectrometry. Figs. 4c.$h$ contain the formation rates of anode and cathode products measured with LCT-Rh/GDC and SFM/GDC electro-catalysts. The values presented in the figure were recorded after steady-state conditions were established $(20-30 \mathrm{~min})$ during the potentiostatic transient experiments. The applied potentials ranged from -0.15 (co-generation) to $1.0 \mathrm{~V}$ (electrolysis) to cover all possible type of operations with the cells. At the anode side, the conversion of methane over LCT-Rh/GDC varied between 3.7-13.4\%, while over SFM/GDC from 0.1-2.1\%.

Interestingly, LCT-Rh was primarily selective towards POM (CO selectivity: 65-100\%) as opposed to SFM (CO selectivity: 13-16\%), which allowed up to 30 times higher syngas yields of an 1.8-2.0 $\mathrm{H}_{2} / \mathrm{CO}$ ratio. In all our measurements of the anode effluents, only traces of $\mathrm{C}_{2}$ hydrocarbons (ethane and ethylene) were measured in the order of 100-300 ppm, confirming POM (eq. 3) and COM (eq.5) as the main and side reaction, respectively. The COM's contribution over LCT-Rh becomes significant as current density rises, and particularly above $0.5 \mathrm{~V}\left(>0.8 \mathrm{~A} \cdot \mathrm{cm}^{-2}\right)$ of applied voltage (Fig. 4c). This finding, and in conjunction with the slight decrease in syngas rate at the same conditions, indicate that at high $\mathrm{O}^{2-}$ fluxes a considerable part of the formed syngas is subsequently oxidized to $\mathrm{CO}_{2}$ and $\mathrm{H}_{2} \mathrm{O}$.

Although numerous studies have been carried out to elucidate the steps leading to the catalytic syngas formation via POM reaction, the exact mechanism is still uncertain ${ }^{40,41}$. To this day, two mechanisms have been proposed for methane conversion to syngas; the direct and the so-called combustion-reforming. The former involves the direct oxidation of adsorbed methane to syngas whereas the latter yields $\mathrm{CO}$ and $\mathrm{H}_{2}$ from reforming reactions either with $\mathrm{CO}_{2}$ (dry) or $\mathrm{H}_{2} \mathrm{O}$ (steam), produced in a first stage by methane complete oxidation ${ }^{40,41}$. In both mechanisms, and generally for all alkanes' activation in heterogeneous catalysis, the rate-determining step is the dissociative adsorption of the fuel on an active site, i.e. the initial cleavage of the $\mathrm{C}-\mathrm{H}$ bond $^{40}$. In the present system, this step is thermodynamically favoured on Rh nanoparticles, since noble metal surfaces, and particularly that of Rh, exhibit the lowest energy barriers for this elementary step ${ }^{40,41}$. Additionally, our electrocatalytic activity results indicate that over LCT-Rh, a direct mechanism is possible since only at high current densities do $\mathrm{CO}_{2}$ and $\mathrm{H}_{2} \mathrm{O}$ concentrations increase at the 
expense of $\mathrm{CO}$ and $\mathrm{H}_{2}$. However, comprehensive studies with advanced in-situ physicochemical characterizations are required to decipher this complex catalytic system.

The $\mathrm{CO}$ and $\mathrm{H}_{2}$ produced in the cathodic compartment $\left(\mathrm{CO}_{2}-\mathrm{H}_{2} \mathrm{O}\right.$ co-electrolysis $)$ of the cell reactor, along with the $\mathrm{CO}_{2}$ conversion at each applied voltage with LCT-Rh/GDC and SFM/GDC electrodes are illustrated in Figs. 4e and 4f. As expected from the enhanced current densities obtained with the Rh-exsolved perovskite (Fig. 4b), syngas rate and $\mathrm{CO}_{2}$ conversion at the cathode were much higher than that of SFM/GDC. In all cases, the faradaic efficiencies measured with both electrodes approached $100 \%$, within a relative error of $5 \%$ in mass balances. Therefore, the current densities in Fig. 4b directly correspond to an electrochemical oxygen flux and syngas generation according to eq.1. With both cathodes, hydrogen constituted the primary product, denoting the dominance of the $\mathrm{H}_{2} \mathrm{O}$ electrolysis process. Nonetheless, as the current rises the $\mathrm{CO}$ formation was improved, and $\mathrm{H}_{2} / \mathrm{CO}$ ratio rapidly declined for both electrodes examined. Specifically, the $\mathrm{H}_{2} / \mathrm{CO}$ ratios measured at the cathode varied from 1.84-2.75 and 2.12-3.49 for SFM and LCT-Rh, respectively.

The $\mathrm{CO}_{2}$ and $\mathrm{H}_{2} \mathrm{O}$ co-electrolysis over the cathode is also a rather complicated process because $\mathrm{CO}$ can be a product of both electro-catalytic $\mathrm{CO}_{2}$ reduction at the active electrochemical zone (three-phase boundary) and the catalytic rWGS reaction (eq. 7) on the electrode's surface. The contribution of each path to $\mathrm{CO}$ formation is still not clear, since it is quite sensitive to the operating conditions (temperature, gas composition, materials etc.) ${ }^{1,4,8-11}$. Moreover, most of the mechanistic studies have been carried out with $\mathrm{Ni} / \mathrm{YSZ}$ cells in presence of a protective $\mathrm{H}_{2}$ atmosphere (to avoid oxidation of $\mathrm{Ni}$ ), further complicating the system by introducing $\mathrm{H}_{2}$ in the gas-phase. In the context of the present study, we performed background experiments for the separate dry $\mathrm{CO}_{2}$ and $\mathrm{H}_{2} \mathrm{O}$ electrolysis over LCT-Rh/GDC and SFM/GDC. For $\mathrm{CO}_{2}$ electrolysis the current densities were inferior to $\mathrm{H}_{2} \mathrm{O}$, albeit, faradaic efficiencies of $80-95 \%$ were acquired with both electrocatalysts. These results suggest that both rWGS and $\mathrm{CO}_{2}$ electrolysis are feasible, even if the latter is kinetically less favoured as to $\mathrm{H}_{2} \mathrm{O}$ electrolysis.

The dependence of the overall reactant consumption and product formation in the cell reactor on the applied voltage is portrayed in Figs. $4 \mathrm{~g}$ and $4 \mathrm{~h}$. It should be noted that $\mathrm{H}_{2} \mathrm{O}$ consumption rate was calculated from $\mathrm{H}_{2}$ and $\mathrm{O}_{2}$ mass-balances. With LCT-Rh cell the total production of syngas was impressive and reached up to $20.6 \mathrm{sccm} \cdot \mathrm{cm}^{-2}$ with a $\mathrm{H}_{2} / \mathrm{CO}$ ratio varying from 1.9-2.2, which 
is ideal for industrial applications such as F-T. The consumed gases were $\mathrm{CH}_{4}\left(1.5-5.4 \mathrm{sccm} \cdot \mathrm{cm}^{-}\right.$ ${ }^{2}$ ) and $\mathrm{H}_{2} \mathrm{O}\left(1.2-4.7 \mathrm{sccm} \cdot \mathrm{cm}^{-2}\right)$, whereas the overall $\mathrm{CO}_{2}$ consumption declined at the highest voltages due to its concurrent formation as a by-product at the anode side. Interestingly, Fig. 4h depicts that up to $10.3 \mathrm{sccm} \cdot \mathrm{cm}^{-2}$ of syngas can be produced without imposing any electrical power, whereas at $-0.15 \mathrm{~V}$, the formation of $5.6 \mathrm{sccm} \cdot \mathrm{cm}^{-2}$ is accompanied by the generation of $\sim 30 \mathrm{~mW} \cdot \mathrm{cm}^{-2}$. To comprehend the exceptional activity of $\mathrm{Rh}$ nanoparticles for MACE process, the total syngas rate with SFM/GDC was $0.06 \mathrm{sccm} \cdot \mathrm{cm}^{-2}$ and the maximum power output did not exceed $2 \mathrm{~mW} \cdot \mathrm{cm}^{-2}$.

\section{Controlling LCT-Rh nanostructure and its effect on the electro-catalytic performance}

To explore the key role of Rh nanoparticles to the functionality of the LCT-Rh electrodes, we adjusted the size and population of the exsolved particles at the surface by changing the reduction temperature of the perovskite. We pretreated LCT-Rh with $5 \% \mathrm{H}_{2} / \mathrm{N}_{2}$ at four different temperatures between 600 and $900{ }^{\circ} \mathrm{C}$, while maintaining the $10 \mathrm{~h}$ exposure time as in the previous experiments. Fig. 5a and 5b display the surface morphology and the properties of the $\mathrm{Rh}$ nanoparticles following the four reduction procedures. The sample treated at $600{ }^{\circ} \mathrm{C}$, resulted in smaller particles $(2.1 \mathrm{~nm}$ average diameter) but with remarkably higher populations $\left(11,000\right.$ particles $\left.\cdot \mu \mathrm{m}^{-2}\right)$ compared to $900{ }^{\circ} \mathrm{C}$ (3.2 $\mathrm{nm}$ average diameter, 5,100 particles $\left.\mu \mathrm{m}^{-2}\right)$. Additionally, the $\mathrm{Rh}$ particles and perovskite backbone interface length significantly increases to 68 from $45 \mu \mathrm{m} \cdot \mu \mathrm{m}^{-2}$ by decreasing the temperature of exposure to $600{ }^{\circ} \mathrm{C}$ (Fig.5b).

Based on the above observations, three LCT-Rh/GDC symmetrical cells were fabricated and reduced at 600,800 and $900{ }^{\circ} \mathrm{C}$ (referred to as RED600, RED800 and RED900). Except from the RED900 sample, used in our studies so far, we selected two new samples for testing; RED800 with similar and RED600 with considerably altered nanostructure properties. Fig. 5c shows the current density for a transient experiment with consequent potentiostatic steps between -0.15 (cogeneration) and $0.5 \mathrm{~V}$ (electrolysis) of $30 \mathrm{~min}$ each. With all imposed potentials, the current density was rather stable with indications of minor activation during the first few minutes of each step. The RED900 exhibited the best electrochemical performance closely followed by RED800, whereas RED600 had similar current densities only at the lower applied potentials. Obviously, the higher oxygen removal rate from the perovskite during reduction at elevated temperatures creates 
more oxygen vacancies in the lattice, and decreases the oxidation state of the B-site cations, thus enhancing the electronic and ionic conductivity of the perovskite electrodes ${ }^{32,35}$.

Nonetheless, the analysis of the gas effluents exiting the anode compartment revealed that the converted methane and CO selectivity (produced via POM) were improved with RED600 (Figs. 5d and 5e). In Fig.5d, we have also plotted as dotted lines the theoretical methane conversion if POM and COM reactions were individually taking place at the anode. Ideally, an electrode which is solely selective to $\mathrm{POM}$, requires four times less $\mathrm{O}^{2-}$ anions, and consequently four times lower current for each $\mathrm{CH}_{4}$ molecule. Since RED600 almost exclusively produces syngas (98-100\% CO selectivity), the methane conversion (up to $18.2 \%$ ) and CO yield (up to $16.8 \%$ ) were higher than RED800 and RED900, even by achieving lower current densities.
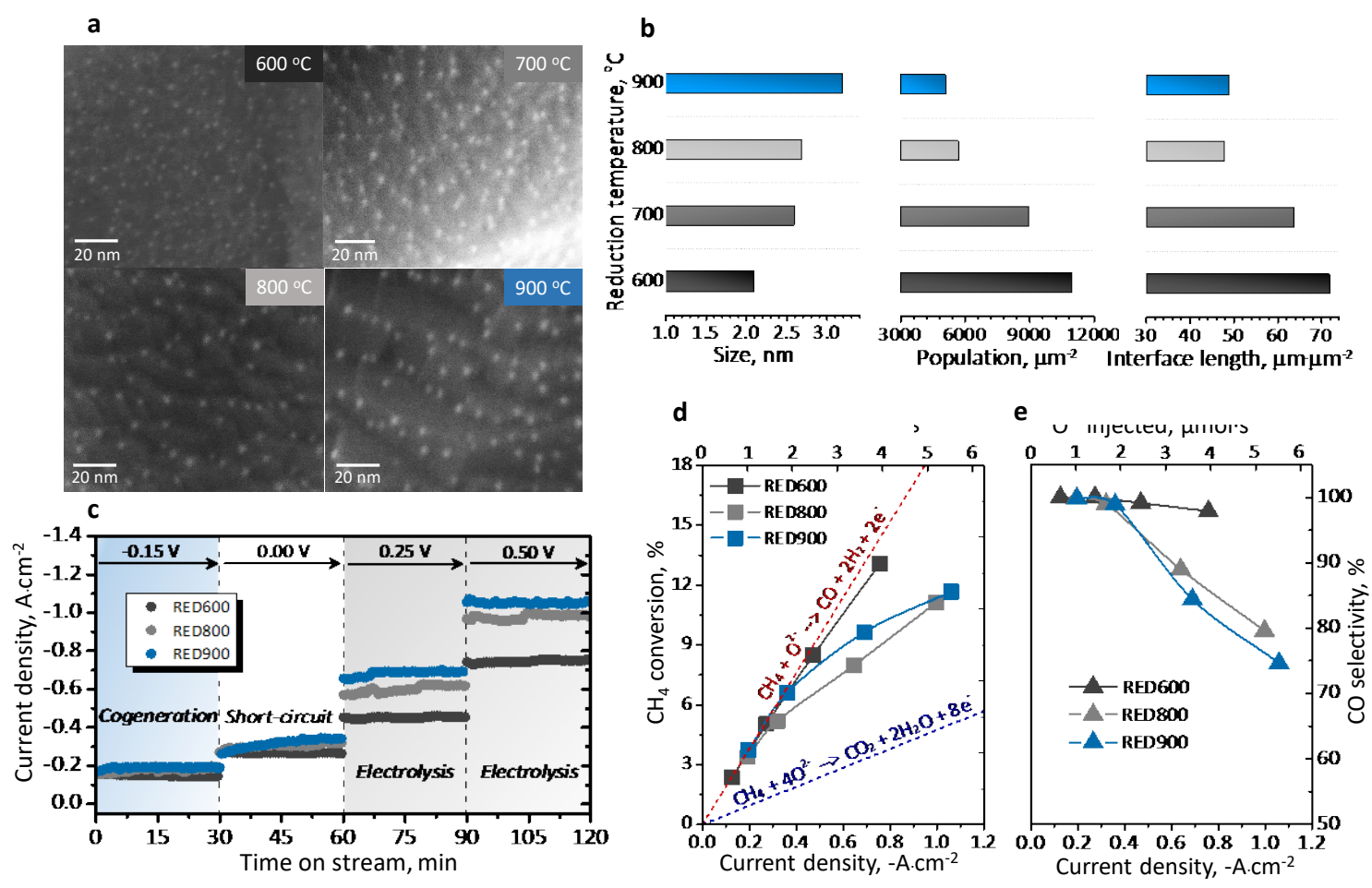

Fig. 5. Effect of pretreatment temperature on $\mathrm{Rh}$ nanoparticles and cell performance for MACE. a. Surface morphology and b. characteristics of Rh nanoparticles resulted from 600-900 ${ }^{\circ} \mathrm{C}$ exposure to hydrogen. c. Effect of time on stream on current density during potentiostatic steps of $-0.15,0.00,0.25$ and $0.50 \mathrm{~V}$, and the corresponding d. $\mathrm{CH}_{4}$ conversion and e. $\mathrm{CO}$ selectivity acquired at steady state with the RED600, RED800 and RED900 samples. In Fig. 5d the dotted 
lines represent methane conversion if POM (red) or COM (blue) were individually taking place at the anode.

Perovskite oxides have been successfully employed as Rh support for the POM reaction in conventional thermal catalytic systems ${ }^{40,41,44}$. In these studies, the size and dispersion degree of $\mathrm{Rh}$ nanoparticles, as well as the reducibility of the support were essential for the mechanism of POM. Here, the highest syngas yields were obtained with RED600 sample (Fig.S8a). This is due to the higher interface length between $\mathrm{Rh}$ and perovskite support that provides enhanced contact area for the reaction of oxygen anions from the perovskite lattice and dissociated methane (or $\mathrm{CH}_{\mathrm{x}}$ radicals) from the $\mathrm{Rh}$ surface. However, by normalizing the methane consumption rate to the interface length (Fig.S8b), RED800 and RED900 samples display almost identical activities which are slightly higher than RED600 at low currents, hence revealing an interaction between the embedded $\mathrm{Rh}$ particles and the perovskite support. It has been proposed that the catalytic activity of $\mathrm{Rh}$ is well connected to its oxidation state, and specifically the closer to metallic state, the higher the number of active sites for methane dissociation ${ }^{40-47}$. Particles with size close or below $2 \mathrm{~nm}$, as in the RED600 sample, are prone to remain in the oxidized $\left(\mathrm{Rh}^{3+}\right.$ and $\left.\mathrm{Rh}^{4+}\right)$, less active state due to the fast exchange of oxygen species with the support, whereas as the particles size increases up to $4 \mathrm{~nm}$, Rh can maintain the desirable reduced state ${ }^{55}$. Further, the extensive exposure of the samples to hydrogen containing atmosphere at elevated temperatures, such as 800 and $900{ }^{\circ} \mathrm{C}$, renders the perovskite support less reducible compared to the pretreatment at $600{ }^{\circ} \mathrm{C}$, which in turn renders oxygen migration towards Rh surface less likely.

Nonetheless, the selectivity to syngas exhibits the opposite trend and declines with increasing the particle size. Similar correlation between size and selectivity has been previously observed in POM kinetic and mechanistic studies on Rh catalysts ${ }^{43}$. It has been suggested that even if the reaction mechanism does not depend on particle size, the involved processes are kinetically controlled and dominate the performance of $\mathrm{Rh}^{43}$. As seen in Fig. 5e, at low current densities and therefore, oxygen supply to the anode, all samples were exclusively selective to POM. The increase in electrochemical oxygen flux by rising current density, however, caused a brisk decline in CO selectivity. This similar trend observed in POM selectivity with $\mathrm{O}^{2-}$ flux indicates an analogous path to methane oxidation with all samples examined. Most probably, as the oxygen concentration at the anode increases, the subsequent oxidation of the produced syngas to $\mathrm{CO}_{2}$ and $\mathrm{H}_{2} \mathrm{O}$ on the 
larger Rh particles of RED800 and RED900 is facilitated, thus leading to the decline in selectivity to POM.

\section{Durability test}

To assess the durability of the perovskite symmetrical cell, we performed a 96-h transient experiment of methane-assisted $\mathrm{CO}_{2}-\mathrm{H}_{2} \mathrm{O}$ co-electrolysis with consecutive potentiostatic steps. For the experiments, we selected the RED900 sample, which exhibited the highest current densities among the cells examined in the previous section. The experimental conditions were identical as in Fig. 4, i.e. dry $40 \% \mathrm{CH}_{4} / \mathrm{N}_{2}$ and $25 \% \mathrm{CO}_{2} / 25 \% \mathrm{H}_{2} \mathrm{O} / 50 \% \mathrm{~N}_{2}$ at the anode and cathode respectively, at $850{ }^{\circ} \mathrm{C}$ operation temperature. Fig. 6a displays the overall formation rates of hydrogen and carbon monoxide exiting the cell reactor, as well as the developed current density under several closed-circuit conditions. Initially, the cell operated with excellent stability for 24-h in syngas-electricity co-generation mode, achieving syngas production of $5.65 \mathrm{sccm} \cdot \mathrm{cm}^{-2}$ with a $2.1 \mathrm{H}_{2} / \mathrm{CO}$ ratio and electrical power of $\sim 30 \mathrm{~mW} \cdot \mathrm{cm}^{-2}$. By switching to short-circuit for the 24-h (no electrical power generation or consumption), the current doubles, leading to an analogous $\mathrm{H}_{2}$ and $\mathrm{CO}$ formation increase $\left(\mathrm{H}_{2}: 3.5\right.$ to $7, \mathrm{CO}: 1.75$ to 3.5$)$. Likewise, by raising the cell voltage to $0.1 \mathrm{~V}$ a current density of $0.56 \mathrm{~A} \cdot \mathrm{cm}^{-2}$ was attained, concurrently releasing $13 \mathrm{sccm} \cdot \mathrm{cm}^{-2}$ of syngas. By returning to short-circuit conditions, the developed current density and selectivity to syngas were practically unaltered and even slightly enhanced, suggesting negligible degradation of the system during the examined time period. These results imply that our cell can operate in several modes depending our needs, simply by switching the applied voltage (or current).

Fig. S9 contain SEM images of the used anode and cathode where minor differences can be observed in the size and population of Rh nanoparticles, corroborating to the exsolved Rh particles robustness due to their socketing nature ${ }^{30,34,36}$. This assumption was recently verified by performing in-situ transmission electron microscopy studies, where the nanoparticles of similar titanate perovskites were observed to grow epitaxially and isotropically, maintaining the initial point of nucleation ${ }^{56}$. Moreover, during the exsolution process, the parent perovskite lattice rise around the particle, thus confining and straining the particle, which in turn enhances thermal resistivity and stability of the particles ${ }^{56}$. EDX analysis verified carbon presence at the anode, most

likely formed by methane cracking due to the low $\mathrm{CH}_{4} / \mathrm{O}_{2}$ molar ratio. In the present durability study, the currents varied from $0.18-0.56 \mathrm{~A} \cdot \mathrm{cm}^{-2}$, corresponding to $0.7-2.1 \mathrm{sccm} \cdot \mathrm{cm}^{-2}$ or a $\mathrm{P}_{\mathrm{CH} 4} / \mathrm{P}_{\mathrm{O} 2}$ 
$=21$. At these conditions carbon formation from methane pyrolysis is inevitable, albeit LCT-Rh retained its exquisite performance. Nevertheless, long-term stability experiments are required to accurately evaluate the effect of carbon presence in POM activity and the overall cell performance.

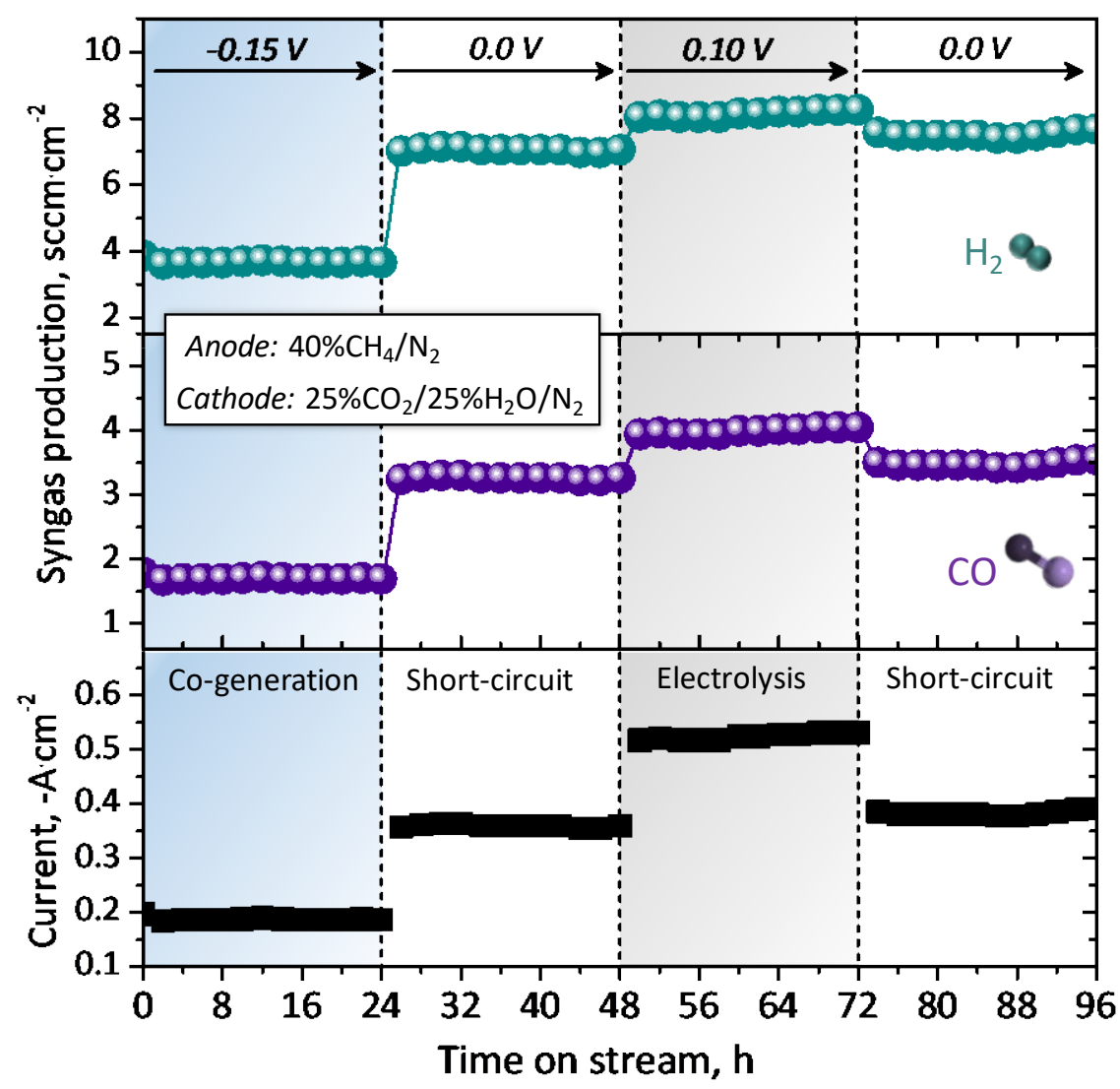

Figure 6. Durability study of the LCT-Rh/GDC symmetrical cell for the methane assisted $\mathrm{CO}_{2}-\mathrm{H}_{2} \mathrm{O}$ co-electrolysis concept. a. Formation rates of hydrogen and carbon monoxide, as well as the developed current densities during the 96 -h potentiostatic transient experiment. Post-mortem SEM images of the anode and cathode are presented in Fig. S9. Reactor inlet: anode feed: $40 \% \mathrm{CH}_{4}-60 \% \mathrm{~N}_{2}$, cathode feed: $25 \% \mathrm{CO}_{2}-25 \% \mathrm{H}_{2} \mathrm{O}-50 \% \mathrm{~N}_{2}$. Operation temperature: $850{ }^{\circ} \mathrm{C}$.

\section{CONCLUSIONS}

A La0.43 $\mathrm{Ca}_{0.37} \mathrm{Rh}_{0.06} \mathrm{Ti}_{0.94} \mathrm{O}_{3}$ (LCT-Rh) ceramic electrode uniformly decorated with exsolved $\mathrm{Rh}$ nanoparticles $(2.1-3.2 \mathrm{~nm})$ after thermal reduction by hydrogen was employed in a symmetrical cell configuration for the methane-assisted co-electrolysis of $\mathrm{CO}_{2}$ and $\mathrm{H}_{2} \mathrm{O}$ concept. By switching 
the anode feed from air to methane fuel $\left(40 \%\right.$ in $\left.\mathrm{N}_{2}\right)$, a remarkable shift of the onset potential to the fuel cell region (from 0.9 to $-0.34 \mathrm{~V}$ ) was observed due to Rh nanocatalysts, and hence, the syngas formation from $\mathrm{CO}_{2}-\mathrm{H}_{2} \mathrm{O}$ at the cathode was accompanied by electricity generation. Additionally, the sacrificed methane reacted over the anode towards syngas (up to $100 \%$ selectivity, $\sim 2.0 \mathrm{H}_{2} / \mathrm{CO}$ ratio), thus constituting the overall process even more attractive. As compared to a state-of-the-art SFM perovskite, LCT-Rh cell performance and syngas formation was up to $800 \%$ improved as to SFM. To further tune the activity of Rh nanoparticles to the functionality of the electrode for methane-to-syngas conversion, we modified the exsolved Rh nanoparticle properties (size and population) by varying the reduction temperature of the perovskite between 600 and $900{ }^{\circ} \mathrm{C}$. The sample reduced at $600{ }^{\circ} \mathrm{C}$ exhibited the smallest particles $(2.1 \mathrm{~nm})$ but with impressive populations of 11,000 particles $\mu \mathrm{m}^{-2}$. This resulted in higher methane conversions to $\mathrm{CO}$ and $\mathrm{H}_{2}$ (yields up to $16.8 \%$ ) than 800 and $900{ }^{\circ} \mathrm{C}$, even at inferior lower current densities. Furthermore, LCT-Rh adequate stability and coking resistance during the 96 -h durability study, holding promise for efficient exploitation of noble metals to activate molecules of low reactivity, such as $\mathrm{CH}_{4}$ and $\mathrm{CO}_{2}$. in challenging energy applications.

\section{EXPERIMENTAL SECTION}

\section{Materials synthesis and cell fabrication}

The LCT-Rh perovskite was prepared by a modified solid state synthesis described in detail previously ${ }^{31,38}$. The $\mathrm{La}_{2} \mathrm{O}_{3}$ (99.99\%, Sigma Aldrich), $\mathrm{CaCO}_{3}$ (99.995\%, Alfa Aesar), $\mathrm{TiO}_{2}$ (99.99\%, Sigma Aldrich) and $\mathrm{Rh}_{2} \mathrm{O}_{3}(99.9 \%$ Rh basis, Sigma Aldrich) precursors were transferred to a beaker, and mixed with acetone and a Hypermer KD-1 non-aqueous dispersant (polyester/polyamide copolymer, $\sim 0.05 \mathrm{wt} . \%$ ). The mixture was homogenized, slowly dried and finally calcined at $1000{ }^{\circ} \mathrm{C}$ for $12 \mathrm{~h}$ to decompose the carbonates and initiate nucleation of the perovskite. The calcined powder was then ball-milled in acetone, pressed into dense pellets and fired at $1100{ }^{\circ} \mathrm{C}$ for $24 \mathrm{~h}$ to obtain a pure perovskite phase. To investigate the contribution of $\mathrm{Rh}$ nanoparticles to the cell performance the undoped, A-site deficient $\mathrm{La}_{0.4} \mathrm{Ca}_{0.4} \mathrm{TiO}_{3}$ (LCT) was also synthesized following the same procedure as described above for LCT-Rh. The LCT-Rh performance was also compared to a state-of-the-art $\mathrm{Sr}_{2} \mathrm{Fe}_{1.5} \mathrm{Mo}_{0.5} \mathrm{O}_{6-\delta}$ (SFM) double perovskite

prepared by a citric acid assisted combustion method ${ }^{25} \cdot \operatorname{Sr}\left(\mathrm{NO}_{3}\right)_{2}, \mathrm{Fe}\left(\mathrm{NO}_{3}\right)_{3} \cdot 9 \mathrm{H}_{2} \mathrm{O}$ and 
$\left(\mathrm{NH}_{4}\right)_{6} \mathrm{Mo}_{7} \mathrm{O}_{24} \cdot 4 \mathrm{H}_{2} \mathrm{O}$ (Sigma Aldrich) were used as precursors, while citric acid aided the combustion process. After combustion, the ashes were calcined at $1100{ }^{\circ} \mathrm{C}$ for $4 \mathrm{~h}$ to form the double perovskite.

The symmetrical cells tested were based on a ScCeSZ solid oxide membrane $(20 \mathrm{~mm}$ diameter, $\sim 150 \mu \mathrm{m}$ thickness, Fuel Cell Materials). Prior to the deposition of each electrode an adhesion layer of GDC was printed $\left(2 \mathrm{mg} \mathrm{cm}^{-2}\right)$ on one side to increase surface roughness of the commercial polished pellets and to bridge the thermal and chemical electrode-electrolyte mismatch ${ }^{13,38}$. To fabricate the electrode powders, LCT-Rh, LCT or SFM were ball-milled together with GDC powder at 60/40 weight ratio, and subsequently were mixed with a terpineol-based ink vehicle. The viscous suspension was screen-printed on the GDC layer $\left(4 \mathrm{mg} \cdot \mathrm{cm}^{-2}\right)$ on both sides and the cell was fired at $1100{ }^{\circ} \mathrm{C}$ for $2 \mathrm{~h}$. Au paste, mesh and wires were used for the electrical contacts. The apparent electrode area was approximately $0.6 \mathrm{~cm}^{2}$.

\section{$\underline{\text { Characterization }}$}

The crystallography and phase purity of the electrodes was examined by room temperature XRD with a Bruker using nickel-filtered $\mathrm{Cu} \mathrm{K}_{\alpha}$ beam operating at $40 \mathrm{kV}, 40 \mathrm{~mA}$ and a scan rate of $0.02^{\circ}$ in the $2 \theta$ range of $20^{\circ}-90^{\circ}$. The Rietveld refinement was carried out using GSAS II. The parameters unlocked and refined were the background (shifted Chebyshev polynomial, 3-6 terms), peak shape, unit cell parameters, atomic coordinates, site occupancies, thermal displacement parameters and microstrain. The crystal structure was constructed by using CrystalMaker X for Windows. The cell morphology was examined by scanning electron microscopy (SEM) by means of a SEM Quanta 3DFEG600 (also equipped with an energy dispersive X-ray spectroscopy (EDX) analyzer) and a high resolution FEI Helios Nanolab 600. Chemical analysis of the samples surface was conducted by X-ray photoelectron spectroscopy (XPS) with a Thermo Fisher Scientific, K-alpha instrument. The elemental analysis was investigated in vacuum $\left(10^{-8} \mathrm{mbar}\right)$ with monochromatic Al-Ka radiation. Quantification was performed based on the area of peaks with sensitivity factors from the Scofield library.

\section{Electrochemical testing}

Electrochemical characterization was performed with an electrochemical workstation (CompactStat, Ivium Technologies B.V.) and the accompanying IviumSoft software. Currentvoltage sweeps were performed with a scan-rate of $0.02 \mathrm{~V} \cdot \mathrm{s}^{-1}$. Potensiostatic electrochemical 
impedance spectroscopy (EIS) under open-circuit voltage (OCV), short-circuit ( $0 \mathrm{~V})$ and electrolysis conditions were carried out with an amplitude of $20 \mathrm{mV}$ in the frequency range of $4 \mathrm{x}$ $10^{5} \mathrm{~Hz}$ to $10^{-2} \mathrm{~Hz}$.

High purity $\mathrm{CH}_{4}, \mathrm{H}_{2}, \mathrm{CO}_{2}, \mathrm{~N}_{2}(99.999 \%$, Air Liquide) and synthetic air gases were used. The gas flows were regulated with mass flow controllers (Brooks). Water vapor was added by bubbling the cathode gas inlet $\left(\mathrm{CO}_{2}-\mathrm{N}_{2}\right)$ stream through a temperature controlled saturator. All pipelines were heated above $120^{\circ} \mathrm{C}$ to avoid water condensation. The analysis of the reactants and products $\left(\mathrm{CH}_{4}, \mathrm{CO}, \mathrm{CO}_{2}, \mathrm{H}_{2}, \mathrm{O}_{2}\right)$ was performed via on-line gas chromatography (SRA instruments) and infra-red spectrometry (Fuji Electric). The conversion of $\mathrm{CH}_{4}$ and selectivity to $\mathrm{CO}$ at the anode compartment were calculated as follows:

$\mathrm{X}_{\mathrm{CH} 4}=\left(\mathrm{r}_{\mathrm{CH} 4, \text { in }}-\mathrm{r}_{\mathrm{CH} 4, \text { out }}\right) / \mathrm{r}_{\mathrm{CH} 4 \text {,in }}$

$\mathrm{S}_{\mathrm{CO}}=\mathrm{r}_{\mathrm{CO}} /\left(\mathrm{r}_{\mathrm{CH} 4, \text { in }}-\mathrm{r}_{\mathrm{CH} 4, \text { out }}\right)$

In equations 8 and $9, \mathrm{r}_{\mathrm{CH} 4}$ represents the $\mathrm{CH}_{4}$ molar rate entering (in) or exiting (out) the reactor cell and $\mathrm{r}_{\mathrm{CO}}$, the molar rate of $\mathrm{CO}$ at the exit of the anode compartment.

\section{SUPPORTING INFORMATION}

Deconvolution of Rh3d XPS spectra, SEM images of LCT-Rh prior, following reduction and after durability study, SEM and EDX of LCT-Rh and SFM-based cells, XRD of SFM, Electrochemical performance of the undoped LCT perovskite, LCT-Rh and SFM for co-electrolysis of $\mathrm{CO}_{2}-\mathrm{H}_{2} \mathrm{O}$.

\section{AUTHOR INFORMATION}

\section{Corresponding author}

*E-mail: V.Kyriakou@differ.nl

\section{ORCID}

Vasileios Kyriakou: https://orcid.org/0000-0002-7088-1160 


\section{Author contributions}

V.K. and M.N.T. conceived the idea of this study, D.N. designed the materials, V.K. designed and performed the electrocatalytic experiments, as well as drafted the manuscript with assistance from D.N. and M.N.T., D.N. collected and analyzed the XRD and SEM with assistance from C.T. and K.K., C.T. and K.K. fabricated the materials, G.Z. and R.S. performed part of the electrochemical and physicochemical characterizations. I.S.M. and M.C.M.S. provided suggestions on the data interpretation and manuscript refinement. M.N.T. supervised the research. M.N.T., I.S.M. and M.C.M.S. secured the funding for the project. All authors discussed the results and commented on the manuscript.

\section{Notes}

The authors declare no competing interest.

\section{ACKNOWLEDGEMENTS}

This work was carried out within the SynCat@DIFFER program between the Dutch institute for fundamental energy research (DIFFER), Eindhoven university of Technology (TU/e) and Syngaschem BV and is funded jointly by the Netherlands Organization for Scientific Research (NWO) and Syngaschem BV. In addition, the work carried out at Newcastle has received financial support from the EPSRC via grants EP/P007767/1, EP/ P024807/1 and EP/R023921/1. The SEM was performed within the Center for Multiscale Electron Microscopy (CMEM) with assistance from I. Schreur-Piet (TU/e) and at Durham University Microscopy Facility. Data supporting this publication are openly available under an 'Open Data Commons Open Database License'. The data, with additional metadata, are available at 10.25405/data.ncl.9731201. The authors also thank E. Langereis (DIFFER) for assisting in illustration.

\section{REFERENCES}

[1] Zheng, Y.; Wang, J.; Yu, B.; Zhang, W.; Chen J.; Qiao J.; Zhang, J. A review of high temperature co-electrolysis of $\mathrm{H} 2 \mathrm{O}$ and $\mathrm{CO} 2$ to produce sustainable fuels using solid oxide 
electrolysis cells (SOECs): advanced materials and technology. Chem. Soc. Rev. 2017, 46, 1427-1463.

[2] Fu, Q.; Mabilat, C.; Zahid, M.; Brissea, A.; Gautier, L. Syngas production via hightemperature steam/CO2 co-electrolysis: an economic assessment. Energy Environ. Sci. 2010, $3,1382-1397$

[3] Zhan, Z.; Kobsiriphat, W.; Wilson, J.R.; Pillai, M.; Kim I.; Barnett, S.A. Syngas Production By Coelectrolysis of $\mathrm{CO} 2 / \mathrm{H} 2 \mathrm{O}$ : The Basis for a Renewable Energy Cycle. Energ. Fuel. 2009, 23, 3089-3096.

[4] Ebbesen, S.D.; Jensen, S.H.; Hauch, A.; Mogensen, M.B. High Temperature Electrolysis in Alkaline Cells, Solid Proton Conducting Cells, and Solid Oxide Cells. Chem. Rev. 2014, 114, 10697-10734.

[5] Sørensen B. 2. Hydrogen. In Hydrogen and Fuel Cells: Emerging Technologies and Applications, 2nd ed., Elsevier, Burlington, 2005; pp 5-94.

[6] Graves, C.; Ebbesen, S.D.; Jensen, S.H.; Simonsen, S.B.; Mogensen, M.B. Eliminating degradation in solid oxide electrochemical cells by reversible operation. Nat Mater. 2015, $14,239-244$.

[7] Stoots, C.M.; O’Brien, J.E.; Herring, J.S.; Hartvigsen, J.J. Syngas Production via HighTemperature Coelectrolysis of Steam and Carbon Dioxide. J. Fuel Cell Sci. Technol. 2009, 6,011014 .

[8] Ebbesen, S.D., Knibbe, R.; Mogensen, M. Co-Electrolysis of Steam and Carbon Dioxide in Solid Oxide Cells. J. Electrochem. Soc. 2012, 159, F482-F489.

[9] Cho, A.; Ko, J.; Kim, B.K.; Han, J.W. Electrocatalysts with Increased Activity for Coelectrolysis of Steam and Carbon Dioxide in Solid Oxide Electrolyzer Cells. ACS Catal. 2019, 9, 967-976.

[10] Chen, X.B.; Guan, C.Z.; Xiao, G.P.; Du, X.L.; Wang, J.Q. Syngas production by high temperature steam/CO2 coelectrolysis using solid oxide electrolysis cells. Faraday Discuss. 2015, 182, 341-351. 
[11] Mahmood, A.; Bano, S.; Yu, J.H.; Lee, K.H. Effect of operating conditions on the performance of solid electrolyte membrane reactor for steam and $\mathrm{CO} 2$ electrolysis. $J$. Membrane Sci. 2015, 473, 8-15.

[12] Niakolas, D.K.; Neofytidis, C.S.; Neophytides, S.G. Effect of Au and/or Mo Doping on the Development of Carbon and Sulfur Tolerant Anodes for SOFCs-A Short Review. Front. Environ. Sci. 2017, 5, 1.

[13] Reytier, M.; Di Iorio, S.; Chatroux, A.; Petitjean, M.; Cren, J.; De Saint Jean, M.; Aicart, J.; Mougin, J. Stack performances in high temperature steam electrolysis and co-electrolysis. Int. J. Hydrog. Energy 2015, 40, 11370-11377.

[14] Aicart, J.; Di Iorio, S.; Petitjean, M.; Giroud, P.; Palcoux, G.; Mougin, J. Transition Cycles during Operation of a Reversible Solid Oxide Electrolyzer/Fuel Cell (rSOC) System. Fuel Cells 2019, 19, 381-388.

[15] Lo Faro, M.; Zignani, S.C.; Trocino, S.; Antonucci, V.; Aricò, A.S. New insights on the coelectrolysis of $\mathrm{CO} 2$ and $\mathrm{H} 2 \mathrm{O}$ through a solid oxide electrolyser operating at intermediate temperatures. Electrochim. Acta 2019, 296, 458-464.

[16] Martinez-Frias, J.; Pham, A.Q.; Aceves, S.M. A natural gas-assisted steam electrolyzer for high-efficiency production of hydrogen. Int. J. Hydrogen Energ. 2003, 28, 483-490.

[17] Wang, W.; Gorte, R.J.; Vohs, J.M. Analysis of the performance of the electrodes in a natural gas assisted steam electrolysis cell. Chem. Eng. Sci. 2008, 63, 765-769.

[18] Ju, H.; Badwal, S.; Giddey, S. A comprehensive review of carbon and hydrocarbon assisted water electrolysis for hydrogen production. Appl. Energy 2018, 231, 502-533.

[19] Garagounis, I.; Kyriakou, V.; Anagnostou, C.; Bourganis, V.; Papachristou, I.; Stoukides, M. Solid Electrolytes: Applications in Heterogeneous Catalysis and Chemical Cogeneration. Ind. Eng. Chem. Res. 2011, 50, 2, 431-472.

[20] Liu, S.; Chuang, K.T.; Luo, J.L. Double-Layered Perovskite Anode with in Situ Exsolution of a Co-Fe Alloy To Cogenerate Ethylene and Electricity in a Proton-Conducting Ethane Fuel Cell. ACS Catal. 2016, 6, 760-768. 
[21] Caravaca, A.; de Lucas-Consuegra, A.; González-Cobos, J.; Valverde, J.L.; Dorado, F. Simultaneous production of $\mathrm{H} 2$ and $\mathrm{C} 2$ hydrocarbons by gas phase electrocatalysis. Appl. Catal. B: Environ. 2012, 113-114, 192-200.

[22] Gür, T.M. Comprehensive review of methane conversion in solid oxide fuel cells: Prospects for efficient electricity generation from natural gas. Prog. Energ. Combust. 2016, 54, 1-64.

[23] Patcharavorachot, Y.; Thongdee, S.; Saebea, D.; Authayanun, S.; Arpornwichanop, A. Performance comparison of solid oxide steam electrolysis cells with/without the addition of methane. Energ. Convers. Manage. 2016, 120, 274-286.

[24] Wang, Y.; Liu, T.; Fang, S.; Xiao, G.; Wang, H.; Chen, F. A novel clean and effective syngas production system based on partial oxidation of methane assisted solid oxide co-electrolysis process. J. Power Sources 2015, 277, 261-267.

[25] Wang, Y., Liu, T.; Lei, L.; Chen, F. Methane assisted solid oxide co-electrolysis process for syngas production. J. Power Sources 2017, 344, 119-127.

[26] Wang, Y.; Xu, J.; Meng, X.; Liu, T.; Chen, F. Ni infiltrated Sr2Fe1.5Mo0.5O6- $\delta-$ $\mathrm{Ce} 0.8 \mathrm{Sm} 0.2 \mathrm{O} 1.9$ electrode for methane assisted steam electrolysis process. Electrochem. Commun. 2017, 79, 63-67.

[27] Zhang, Y.; Han, M. Energy storage and syngas production by switching cathode gas in nickel-yttria stabilized zirconia supported solid oxide cell. Appl. Energy, 2019, 241, 1-10.

[28] Lee, K.J.; Lee, M.; Hwang, H. High-temperature steam electrolysis combined with methane partial oxidation by solid oxide electrolyzer cells. Appl. Surf. Sci. 2019, 473, 746-749.

[29] Liu, T.; Liu, H.; Zhang, X.; Lei, L.; Zhang, Y.; Yuan, Z.; Chen, F. Wang, Y. A robust solid oxide electrolyzer for highly efficient electrochemical reforming of methane and steam. $J$. Mater. Chem. A 2019, 7, 13550-13558.

[30] Lu, J.; Zhu, C., Pan, C.; Lin, W., Lemmon, J.P.; Chen, F.; Li, C.; Xie, K. Highly efficient electrochemical reforming of $\mathrm{CH} 4 / \mathrm{CO} 2$ in a solid oxide electrolyser. Sci. $A d v$. 2018, 4, eaar5100. 
[31] Neagu, D.; Irvine, J.T.S. Enhancing Electronic Conductivity in Strontium Titanates through Correlated A and B-Site Doping. Chem. Mater. 2011, 23, 1607-1617.

[32] Tsekouras, G.; Neagu, D.; Irvine, J.T.S. Step-change in high temperature steam electrolysis performance of perovskite oxide cathodes with exsolution of B-site dopants. Energy Environ. Sci. 2013, 6, 256-266.

[33] Neagu, D.; Tsekouras, G.; Miller, D.N.; Menard, H.; Irvine, J.T.S. In situ growth of nanoparticles through control of non-stoichiometry. Nat. Chem. 2013, 5, 916-923.

[34] Neagu, D.; Oh, T.S.; Miller, D.N.; Menard, H.; Bukhari, S.M.; Gamble, S.F.; Gorte, R.J.; Vohs, J.M.; Irvine, J.T.S. Nano-socketed nickel particles with enhanced coking resistance grown in situ by redox exsolution. Nat. Commun. 2015, 6, 8120.

[35] Myung, J.H.; Neagu, D.; Miller, D.N.; Irvine, J.T.S. Switching on electrocatalytic activity in solid oxide cells. Nature 2016, 537, 528-531.

[36] Irvine, J.T.S.; Neagu, D.; Verbraeken, M.C.; Chatzichristodoulou, C.; Graves, C.; Mogensen, M.B. Evolution of the electrochemical interface in high-temperature fuel cells and electrolysers. Nat. Energy 2016, 1,15014.

[37] Kim, K.J.; Rath, M.K.; Kwak, H.H.; Kim, H.J.; Han, J.W.; Hong, S.T.; Lee, K.T. A Highly Active and Redox-Stable SrGdNi0.2Mn0.8O4 $\pm \delta$ Anode with in Situ Exsolution of Nanocatalysts. ACS Catal. 2019, 9, 1172-1182.

[38] Kyriakou, V.; Neagu, D.; Papaioannou, E.I.; Metcalfe, I.S.; van de Sanden, M.C.M.; Tsampas, M.N. Co-electrolysis of $\mathrm{H} 2 \mathrm{O}$ and $\mathrm{CO} 2$ on exsolved Ni nanoparticles for efficient syngas generation at controllable H2/CO ratios. Appl. Catal. B: Environ. 2019, 258, 117950.

[39] Dimitrakopoulos, G.; Ghoniem, A. F.; Yildiz B.; In situ catalyst exsolution on perovskite oxides for the production of $\mathrm{CO}$ and synthesis gas in ceramic membrane reactors. Sustain. Energ. Fuels. 2019, 3, 2347-2355.

[40] Enger, B.C.; Lødeng, R.; Holmen, A. A review of catalytic partial oxidation of methane to synthesis gas with emphasis on reaction mechanisms over transition metal catalysts. Appl. Catal., A 2008, 346, 1-27. 
[41] Sengodan, S.; Lan, R.; Humphreys, J.; Du, D.; Xu W.; Wang, H.; Tao S. Advances in reforming and partial oxidation of hydrocarbons for hydrogen production and fuel cell applications. Renew. Sustain. Energy Rev. 2018, 82, 761-780.

[42] Scarabello, A.; Nogare, D.D.; Canu, P.; Lanza, R. Partial oxidation of methane on Rh/ZrO2 and $\mathrm{Rh} / \mathrm{Ce}-\mathrm{ZrO} 2$ on monoliths: Catalyst restructuring at reaction conditions, Appl. Catal. B: Environ. 2015, 174, 308-322.

[43] Kondratenko, V.A.; Berger-Karin, C.; Kondratenko, E.V. Partial Oxidation of Methane to Syngas Over $\gamma$-Al2O3 -Supported Rh Nanoparticles: Kinetic and Mechanistic Origins of Size Effect on Selectivity and Activity, ACS Catal. 2014, 4, 3136-3144.

[44] Palcheva, R.; Olsbye, U.; Palcut, M.; Rauwel, P.; Tyuliev, G.; Velinov, N.; Fjellvåg, H.H. $\mathrm{Rh}$ promoted $\mathrm{La} 0.75 \mathrm{Sr} 0.25(\mathrm{Fe} 0.8 \mathrm{Co} 0.2) 1-\mathrm{xGaxO}-\delta$ perovskite catalysts: Characterization and catalytic performance for methane partial oxidation to synthesis gas. Appl. Surf. Sci. 2015, 357, 45-54.

[45] Baranova, E.A.; Fóti, G.; Comninellis, C.; Current-assisted activation of Rh/TiO2/YSZ catalyst, Electrochem. Commun. 2004, 6, 389-394.

[46] Zhu, Y.; Zhang, S.; Shan, J.J.; Nguyen, L.; Zhan, S.; Gu, X.; Tao, F. In Situ Surface Chemistries and Catalytic Performances of Ceria Doped with Palladium, Platinum, and Rhodium in Methane Partial Oxidation for the Production of Syngas. ACS Catal. 2013, 3 (11), 2627-2639.

[47] Wu, J.; Qiao, L.; Zhou, Z.; Cui, G.; Zong, S.S.; Xu, D.J.; Ye, R.P.; Chen, R.; Si, R.; Yao, Y.G. Revealing the Synergistic Effects of Rh and Substituted La2B2O7 (B = Zr or Ti) for Preserving the Reactivity of Catalyst in Dry Reforming of Methane. ACS Catal. 2019, 9 (2), 932-945.

[48] Yentekakis, I.V.; Goula, G.; Hatzisymeon, M.; Betsi-Argyropoulou, I.; Botzolaki, G.; Kousi, K.; Kondarides, D.I.; Taylor, M.J.; Parlett, C.M.A.; Osatiashtiani, A.; Kyriakou, G.; Holgado, J.P.; Lambert, R.M. Effect of support oxygen storage capacity on the catalytic performance of Rh nanoparticles for $\mathrm{CO} 2$ reforming of methane. Appl. Catal. B Environ. 2019, 243, 490-501. 
[49] Goula, G.; Botzolaki, G.; Osatiashtiani, A.; Parlett, C.M.A.; Osatiashtiani, A.; Kyriakou, G.; Lambert, R.M.; Yentekakis, I.V. Syngas production via the biogas dry reforming reaction over Ni supported on zirconia modified with $\mathrm{CeO} 2$ or La2O3 catalysts. Catalysts 2019, 9, 541-557.

[50] Kauppinen, M.M.; Melander, M.; Bazhenov, A.S; Honkala, K. Unraveling the Role of the $\mathrm{Rh}-\mathrm{ZrO} 2$ Interface in the Water-Gas-Shift Reaction via a First-Principles Microkinetic Study. ACS Catal. 2018, 8 (12), 11633-11647.

[51] Bao, J.; Yang, G.; Yoneyama, Y.; Tsubaki, N.; Significant Advances in C1 Catalysis: Highly Efficient Catalysts and Catalytic Reactions. ACS Catal. 2019, 9 (4), 3026-3053.

[52] Whang, H.S.; Lim, J.; Choi, M.S.; Lee, J.; Lee, H. Heterogeneous catalysts for catalytic CO2 conversion into value-added chemicals, BMC Chem. Eng. 2019, 1, 9.

[53] Bonincontro, D.; Quadrelli, E.A. $\mathrm{CO}_{2}$ Reduction Reactions by Rhodium-Based Catalysts. In: Rhodium Catalysis. Topics in Organometallic Chemistry, Claver C., Ed.; Springer, Cham, Switzerland, 2016, 61, pp 263-282.

[54] Arandiyan, H.; Wang, Y.; Scott, J.; Mesgari, S.; Dai, H.; Amal, R. In Situ Exsolution of Bimetallic Rh-Ni Nanoalloys: a Highly Efficient Catalyst for CO2 Methanation. ACS Appl. Mater. Interfaces. 2018, 10 (19) 16352-16357.

[55] Ligthart D. A. J. M.; van Santen R. A.; Hensen E. J. M. Supported rhodium oxide nanoparticles as highly active CO oxidation catalysts. Angew. Chem. Int. Ed. 2011, 50, 5306-5310

[56] Neagu, D.; Kyriakou, V.; Roiban, I.-L.; Aouine, M.; Tang, C.; Caravaca, A.; Kousi, K.; Schreur-Piet, I.; Metcalfe, I. S.; Vernoux, P.; van de Sanden, M. C. M.; Tsampas, M. N. In Situ Observation of Nanoparticle Exsolution from Perovskite Oxides: From Atomic Scale Mechanistic Insight to Nanostructure Tailoring. ACS Nano. 2019, 13, 12996-13005. 